\title{
EXPERIMENTAL ANALYSIS TO COMPARE THE DEFLECTION OF STEEL BEAM WITH AND WITHOUT WEB OPENINGS
}

\author{
Resmi Mohan ${ }^{1}$, Preetha Prabhakaran ${ }^{2}$ \\ ${ }^{1}$ M.Tech Student, Civil Department, Sree Narayana Gurukulam College of Engineering, Kerala, India \\ ${ }^{2}$ Associate Professor, Civil Department, Sree Narayana Gurukulam College of Engineering, Kerala, India
}

\begin{abstract}
As a result of decreasing the cost of steel structures and increasing the stiffness of steel members, several new methods have been adopted. Castellated beams are one of the solutions.Castellated beams refer to a metal beam in which the web portion is firstly divided by a zigzag cut along its lengthwise direction and then welding together its two halves. During welding, the two halves are joined together in such a way that holes are formed in the web portion. This increases the depth of the section and thereby its strength. Castellation means holes. Openings are provided in web portion for the allowance of passage of services through the beam. As the provisions are provided through the web portions, it will help to reduce the effective floor depth. For roofs supported by cambered beams, aesthetic beauty may be considered as an advantage. As castellated beams are same as that of a solid beam, its erection is not a difficult task. In this paper, experimental analysis was conducted to compare the deflection of steel beam without web opening and castellated beam having hexagonal and circular opening. ISMB 150 was selected as the parent section and was used for the fabrication of castellated beams with hexagonal openings and circular openings (cellular beam). Experimental analysis was performed and from that the better shape was determined. Experimental analysis showed that castellated beams having hexagonal openings have more load carrying capacity and lesser deflection as compared to solid beam and beam with circular openings.
\end{abstract}

Keywords: Castellated beam, Deflection, Web opening, Cellular beam $* * *$

\section{INTRODUCTION}

There are many structures using steel as there constructional element. In order to decrease the cost of steel structures and increasing the stiffness of steel members, castellated beams have been developed. Castellated beams are beams with holes in its web portion. Such beams are fabricated by cutting a zigzag pattern in its web portion and then welding together the two halves in such a way that the holes are formed in the web portion. Due to its availability and cheap labour cost, castellated beams were used in early 1950s in Europe. By splitting and then expanding the steel section modulus is increased.

Presence of openings causes many failures modes in the web portions that are not visible in the solid webs. Web post buckling is one such failure. Such failures can be reduced by the introduction of stiffeners along the web opening.

Castellated beams are strong, cheap, easy to assemble and have class. In this work, we are considering steel beam without openings and castellated beam with hexagonal and circular openings (cellular beams). The main advantage of the steel castellated beams is that we can modify the strength of the beam by changing its depth without adding any steel. The modified castellated beam is $50 \%$ deeper and much stronger than the original beam.

Experimental study was conducted on steel beam with and without web openings. Deflection is determined after loading and the better one was selected having maximum load carrying capacity and lesser deflection value.

\section{EXPERIMENTAL PROGRAME}

IS MB 150 section is selected as the parent section for fabricating castellated beam. The castellated beams are fabricated such that the depth of the beam is 1.5 times the original depth as IC 225. Thickness of flange is $5 \mathrm{~mm}$, thickness of web is $5 \mathrm{~mm}$, depth of opening is $150 \mathrm{~mm}$, and length of the beam is $975 \mathrm{~mm}$. Universal testing machine (UTM) is used for testing the castellated beam. Below figures shows the schematic diagram of parent section, castellated steel beam with hexagonal and circular opening used for the analysis. Fig-1. shows the schematic diagram of parent section, Fig -2. shows the schematic diagram of beam with hexagonal opening and Fig-3. shows the schematic diagram of beam with circular opening. 


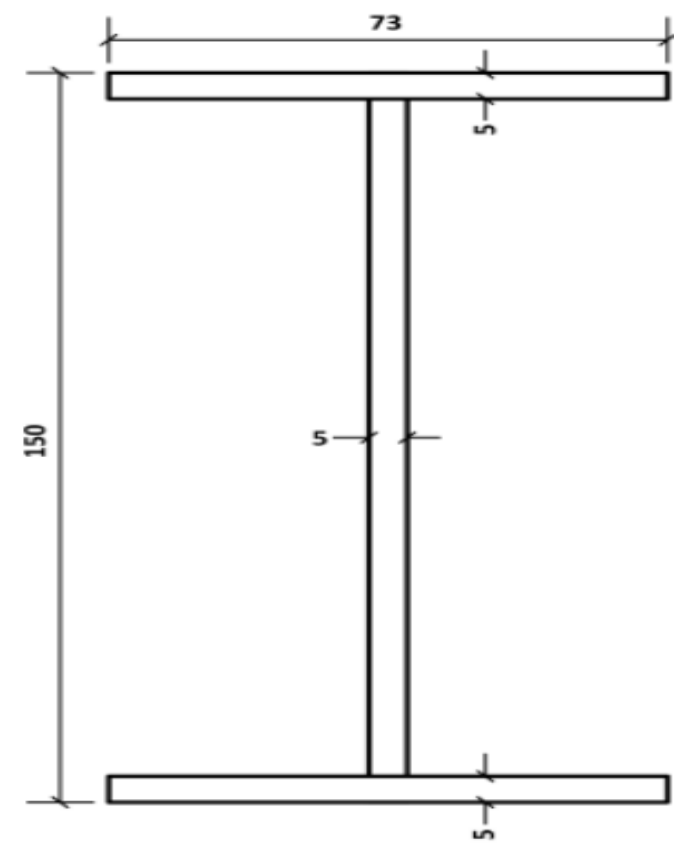

All dimensions are in $\mathrm{mm}$

Fig-1:Schematic diagram of parent section

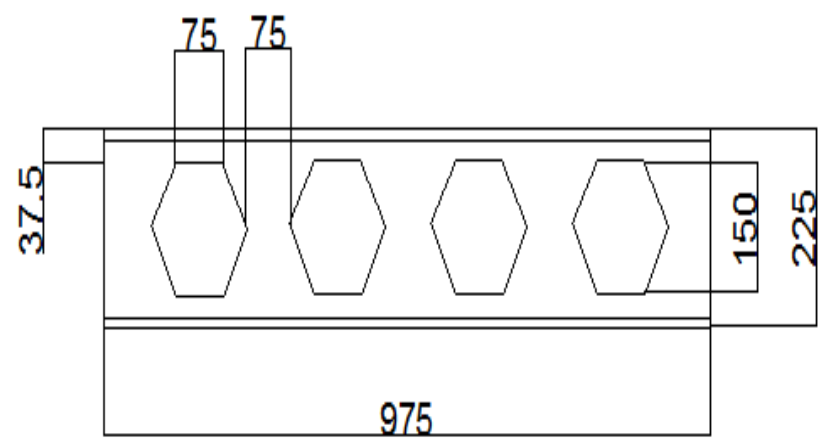

All dimensions are in $\mathrm{mm}$

Fig-2:Schematic diagram of steel beam with hexagonal openings

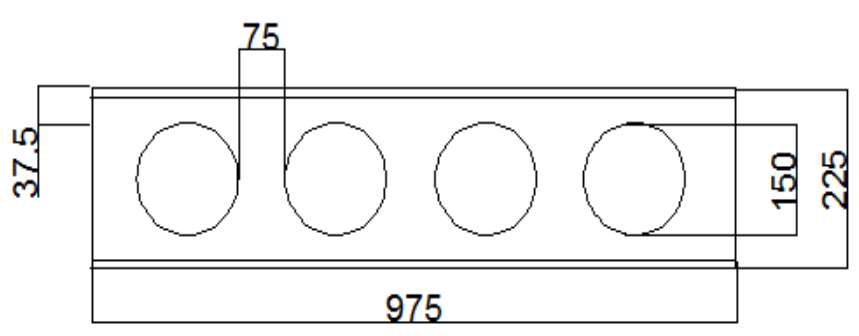

All dimensions are in $\mathrm{mm}$

Fig-3:Schematic diagram of steel beam with circular openings

\section{FABRICATION OF CASTELLATED BEAM}

IS MB150 section of depth $150 \mathrm{~mm}$ is selected for the fabrication of solid as well as castellated beam. Markings for which cutting should be done was made and then gas cutting machine is used to cut the specimen along its markings. After cutting, the two pieces were welded together to form a castellated beam.

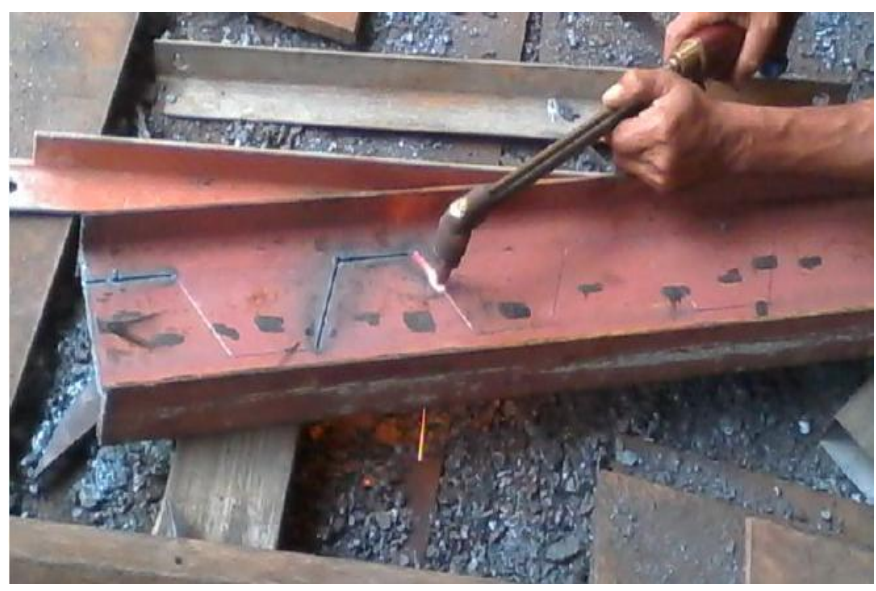

Fig-4: Gas cutting of hexagonal shaped openings

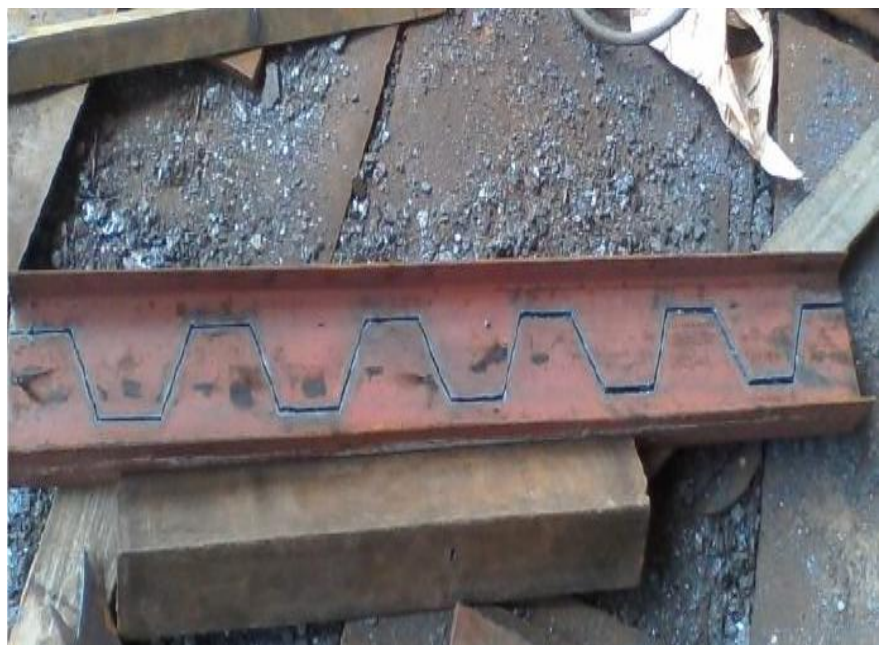

Fig-5: Gas cutting done through the markings for hexagonal shaped openings

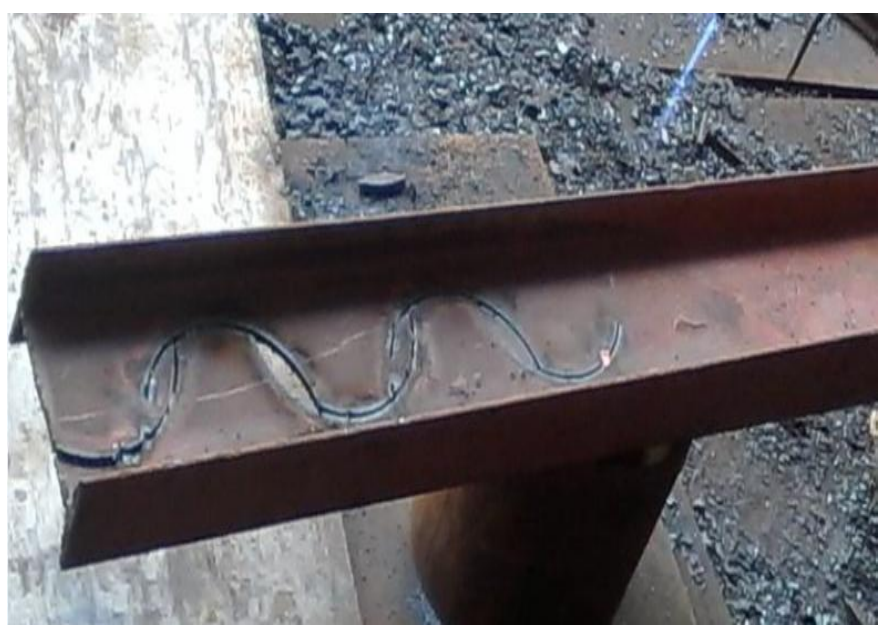

Fig-6:Gas cutting of circular shaped openings 


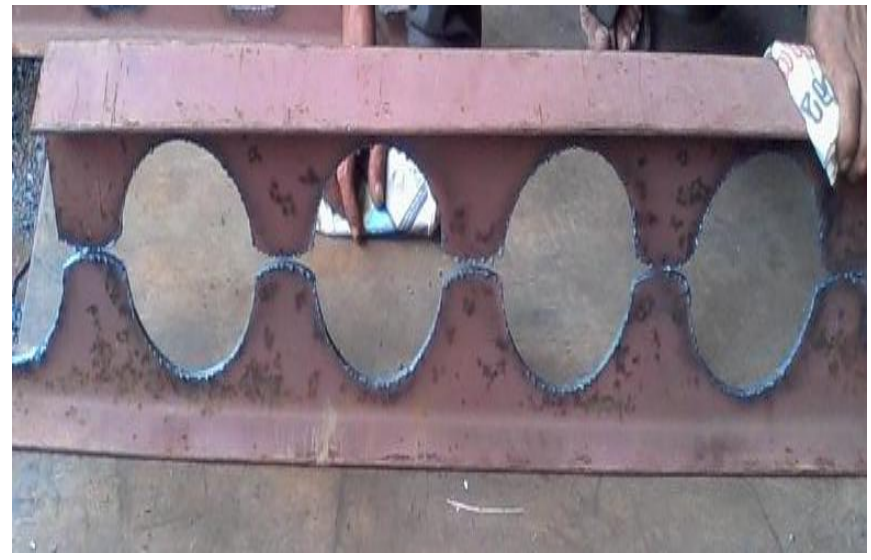

Fig-7:Gas cutting done through the markings for circular shaped openings

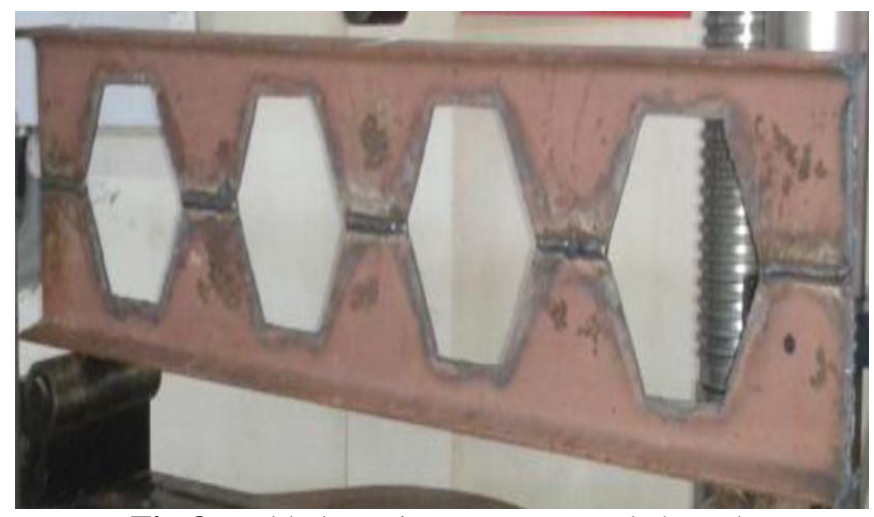

Fig-8:Welded specimen- Hexagonal shaped

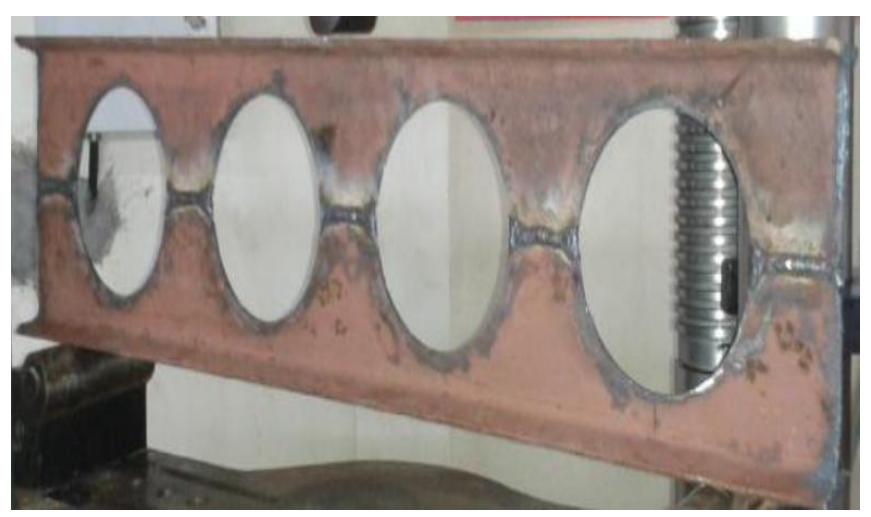

Fig-9:Welded specimen- Circular shaped

\section{TEST PROCEDURE}

The specimens were loaded in universal testing machine (UTM) of $1000 \mathrm{KN}$ capacity. The specimen was supported at two ends. All specimens were loaded at its midpoint slowly until buckling. The load corresponding to the failure of specimen is noted. The experimental set up is shown below. IS MB 150 solid section was also tested to determine the deflection

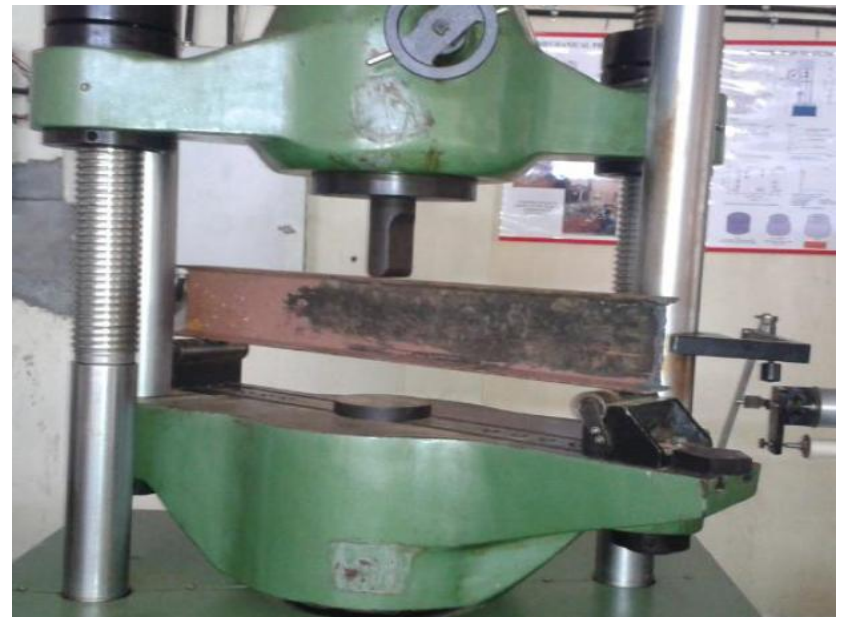

Fig-10: Solid beam before loading

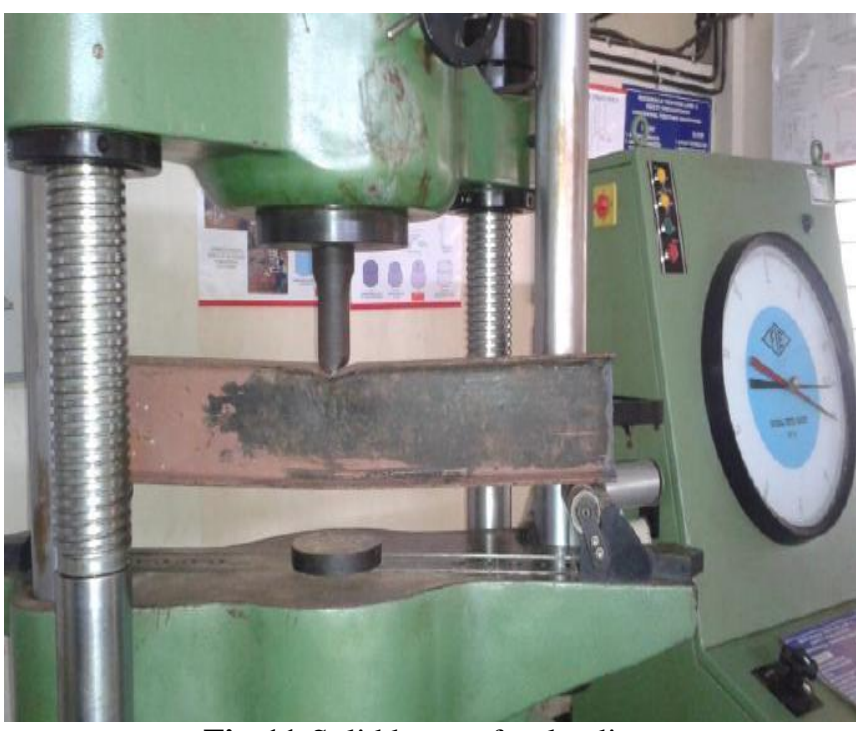

Fig-11:Solid beam after loading

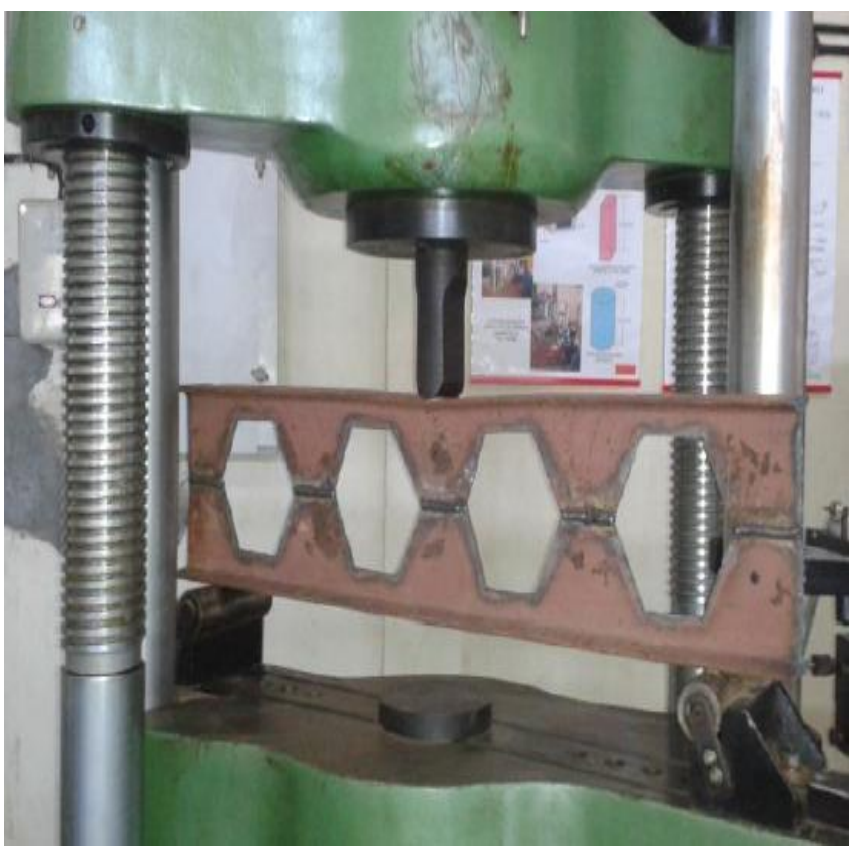

Fig-12:Deflection of steel beam with hexagonal opening (front view) 


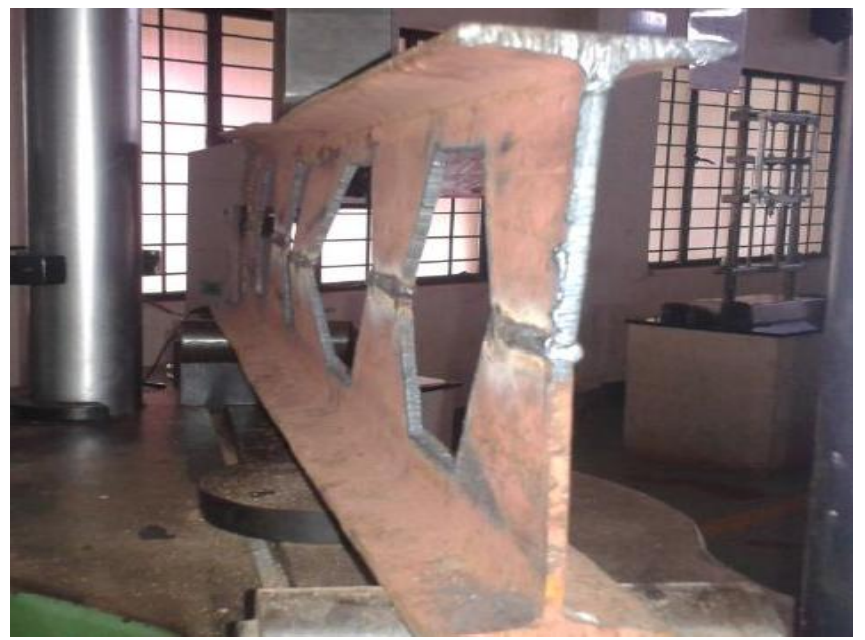

Fig-13:Deflection of steel beam with hexagonal opening (side view)

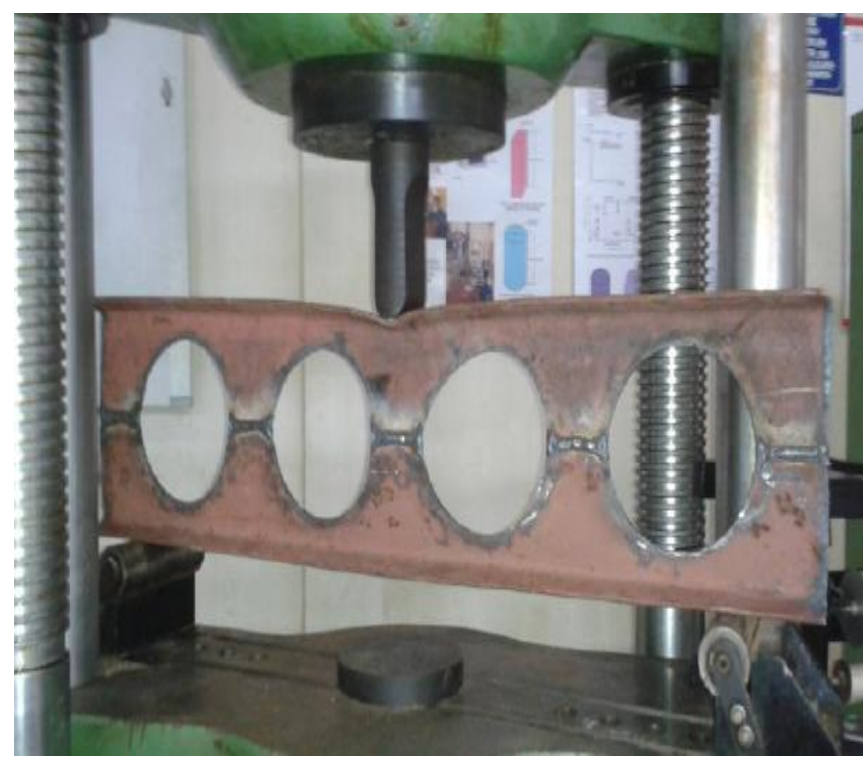

Fig-14:Deflection of steel beam with circular opening (front view)

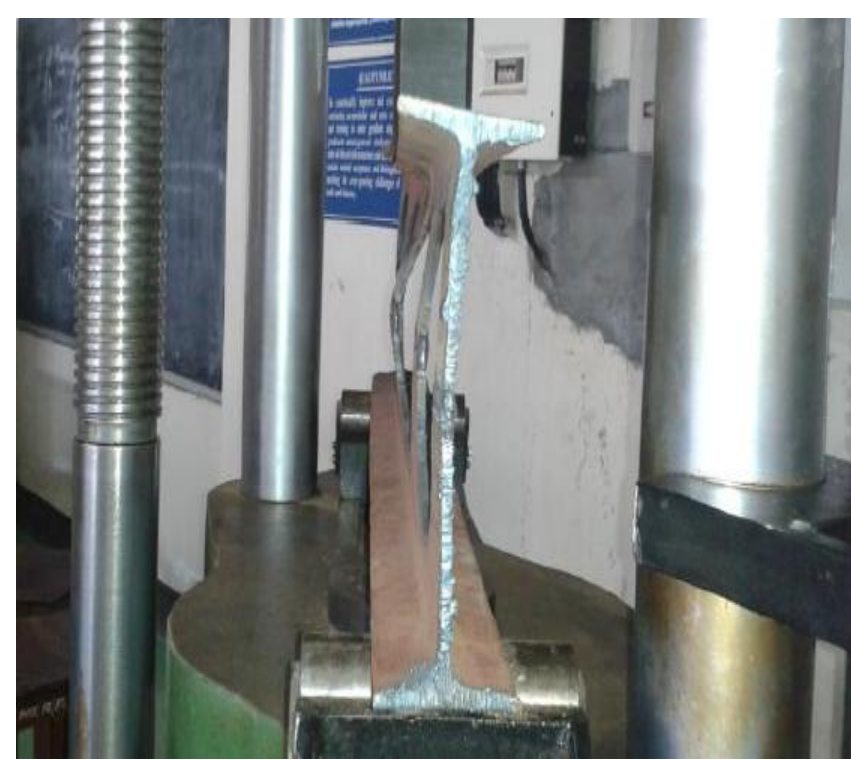

Fig-15:Deflection of steel beam with circular opening (side view)

\subsection{TEST RESULTS}

Below tables show the deflection values of steel beam without opening, with hexagonal openings and with circular openings.

\begin{tabular}{|c|c|c|}
\multicolumn{3}{c}{ Table -1: Deflection of solid beam } \\
\hline S1.No & Load $(\mathrm{kN})$ & Deflection $(\mathrm{mm})$ \\
\hline 1 & 20 & 1 \\
\hline 2 & 40 & 2 \\
\hline 3 & 60 & 3 \\
\hline 4 & 80 & 4 \\
\hline 5 & 100 & 4 \\
\hline 6 & 120 & 5 \\
\hline 7 & 140 & 12 \\
\hline 8 & 156 & 18 \\
\hline
\end{tabular}

Table -2: Deflection of steel beam with circular openings

\begin{tabular}{|c|c|c|}
\hline Sl.No & Load $(\mathrm{kN})$ & Deflection $(\mathrm{mm})$ \\
\hline 1 & 20 & 3 \\
\hline 2 & 40 & 5 \\
\hline 3 & 60 & 6 \\
\hline 4 & 80 & 7 \\
\hline 5 & 100 & 9 \\
\hline 6 & 106 & 12 \\
\hline
\end{tabular}

Table -3: Deflection of steel beam with hexagonal openings

\begin{tabular}{|c|c|c|}
\hline Sl. No & Load $(\mathrm{kN})$ & Deflection $(\mathrm{mm})$ \\
\hline 1 & 20 & 3 \\
\hline 2 & 40 & 3 \\
\hline 3 & 60 & 4 \\
\hline 4 & 80 & 5 \\
\hline 5 & 100 & 6 \\
\hline 6 & 120 & 7 \\
\hline 7 & 140 & 10 \\
\hline 8 & 146 & 10 \\
\hline
\end{tabular}


From the experiments analysis it was clear that castellated beams having hexagonal opening have more load carrying capacity than solid beam and steel beam with circular opening. So it will be better if castellated steel beams with hexagonal openings are used instead of other shapes.

\section{CONCLUSIONS}

- From the experimental analysis, it was observed that, as compared to solid beam and steel beam with circular opening, steel beam with hexagonal opening showed more load carrying capacity.

- Steel beam with hexagonal opening showed more strength because during its fabrication process there is no loss of material, but for the fabrication of circular opening there is loss of materials.

\section{REFERENCES}

[1]. B.Anupriya, Dr.K. Jagadheesan," Strength study on Castellated Beam", International Journal of Engineering Research and Technology,(2013)

[2]. Wakchaure M.R, Sagade A.V, Auti V.A," Parametric study of Castellated Beam with varying depth of web opening", International Journal of Scientific and Research publications, Vol.2, Issue 8(2012)

[3]. A.V Sagade ," Finite Element Analysis of Castellated Steel Beam", International Journal of Engineering and Innovative Technology, Vol 2, Issue 1 (2014)

[4]. A.M Jamadar, P.D Kumbhar," Finite Element Analysis of Castellated Beam: A Review", International Journal of Innovative Research in Advanced Engineering, Vol 1, Issue 9, (2014)

[5]. Prof. R.R Jichkar, Prof N.S. Arukia, "Analysis of steel beam with web openings subjected to buckling load", International Journal of Engineering and Applications,(2014) 